\title{
PATIENTS WITH ACUTE MYOCARDIAL INFARCTION AND INTERFERING FACTORS WHEN SEEKING EMERGENCY CARE: IMPLICATIONS FOR HEALTH EDUCATION
}

\author{
Betina Franco ${ }^{1}$ \\ Eneida Rejane Rabelo ${ }^{2}$ \\ Silvia Goldemeyer ${ }^{3}$ \\ Emiliane Nogueira de Souza ${ }^{4}$
}

Franco B, Rabelo ER, Goldemeyer S, Souza EN. Patients with acute myocardial infarction and interfering factors when seeking emergency care: implications for health education. Rev Latino-am Enfermagem 2008 maiojunho; 16(3):414-8.

With the objective of estimating the time elapsed between the beginning of the signs and symptoms of a heart attack until the arrival at the cardiology emergency service (Delta T) and the factors that influence in this process, 112 patients were studied, with an infarction diagnosis with supraunleveling ST segment. The delta $T$ was on average of 3h59 2 h55min; 99(88\%) of those patients sought out an emergency service within $1 \mathrm{~h}$ after the beginning of the event. Unmarried patients presented a delta $T$ smaller in relation to the others $(P=0,006)$, as well as those that recognized the symptoms as a heart event; thoracic pain with burning symptoms, were described by 25 (24\%) of patients, and the first attitude taken, in view those symptoms, was selfmedication $37(33 \%)$. The recognition of the signs and symptoms of Acute Myocardium Infarction, is a decisive factor for the seeking of a specialized service.

DESCRIPTORS: myocardial infarction; signs and symptoms; time; nursing

\section{PACIENTES CON INFARTO DEL MIOCÁRDIO AGUDO Y LOS FACTORES QUE INTERFIEREN EN LA BÚSQUEDA DE UN SERVICIO DE EMERGENCIA: IMPLICACIONES PARA LA EDUCACIÓN EN SALUD}

Con el objetivo de estimar el tiempo transcurrido entre el inicio de las señales y síntomas del infarto hasta la llegada al sector de emergencia cardiológica (delta T) y los factores que influenciaron ese proceso, se estudiaron 112 pacientes, con diagnóstico de infarto con elevación del segmento ST. El delta T fue en promedio de 3h59min \pm 2 h55min, siendo que $99(88 \%)$ de esos pacientes buscaron un servicio de emergencia una hora después el inicio del evento. Pacientes solteros presentaron un delta T menor en relación a los demás $(P=0,006)$, así como aquellos que reconocieron los síntomas como un evento cardíaco; dolor torácico con ardor fue relatado por $25(24 \%)$ pacientes, siendo que la primera actitud tomada ante esos síntomas fue la automedicación $37(33 \%)$. Se concluyó que el reconocimiento de las señales y de los síntomas de IMA por el paciente es un factor determinante en la búsqueda de atención especializada.

DESCRIPTORES: infarto del miocárdio; sígnos y sintomas; tiempo; enfermería

\section{PACIENTES COM INFARTO AGUDO DO MIOCÁRDIO E OS FATORES QUE INTERFEREM NA PROCURA POR SERVIÇO DE EMERGÊNCIA: IMPLICAÇÕES PARA A EDUCAÇÃO EM SAÚDE}

Com o objetivo de estimar o tempo decorrido entre o início dos sinais e sintomas do infarto até a chegada ao setor de emergência cardiológica (delta T) e os fatores que influenciaram esse processo, estudouse 112 pacientes, com o diagnóstico de infarto com supradesnível do segmento ST. O delta T foi, em média, de 3 h59min \pm 2 h55min, sendo que 99(88\%) desses pacientes procuraram por serviço de emergência uma hora após o início do evento. Pacientes solteiros apresentaram delta $T$ menor em relação aos demais $(p=0,006)$, assim, como aqueles que reconheceram os sintomas como evento cardíaco; dor torácica em ardência foi relatada por $25(24 \%)$ pacientes, sendo que a primeira atitude tomada diante desses sintomas foi a automedicação $37(33 \%)$. Concluiu-se que o reconhecimento dos sinais e dos sintomas de infarto agudo do miocárdio (IAM) pelo paciente é fator determinante para a procura por atendimento especializado.

DESCRITORES: infarto do miocárdio; sinais e sintomas; tempo; enfermagem

${ }^{1}$ Specialist in Cardiology Nursing, Assistant Nurse; ${ }^{2}$ Ph.D. in Biological Sciences, Faculty; ${ }^{3}$ M.Sc. in Cardiology, Faculty; ${ }^{4}$ M.Sc. in Cardiology, Faculty Cardiology Institute, Fundação Universitária de Cardiologia 


\section{INTRODUCTION}

Despite coronary care units, improved fibrinolytic therapy and new percutaneous coronary intervention procedures, acute myocardial infarction (AMI) has been the main cause of death because of its high incidence and prehospital mortality ${ }^{(1)}$. According to electrocardiographic criteria, there are two different kinds of AMI with therapeutic differences ${ }^{(2)}$, which are AMI with strongly uneven ST segments and AMI without strongly uneven ST segments. Therapy for AMI patients without strongly uneven ST is similar to therapy for unstable angina. AMI Patients with strongly uneven ST are treated with thrombolytics and percutaneous transluminal coronary angioplasty (PTCA), with or without stent ${ }^{(1)}$. Treatment for AMI with strongly uneven ST is mainly related to the length of the reperfusion therapy. Arterial recanalization applied at the right time entails several benefits for ventricular function maintenance and for a longer life ${ }^{(3)}$. People must be aware of the signs and symptoms of the patients and look for emergency service in order to decrease morbimortality ${ }^{(1)}$.

According to several studies, only $20 \%$ of acute thoracic pain patients arrive at the emergency room within two hours after the start of the symptoms ${ }^{(3-4)}$, because they may not know that it is a heart condition; it happens because of their low socioeconomic level, because they are female or because of self medication ${ }^{(5)}$. One study states that patients in Brazil do not seek healthcare services promptly because they do not recognize AMI symptoms, because they do not accept what they are feeling, because first aid is not specialized and because of bad public transportation ${ }^{(6)}$. Identifying the reasons why patients delay the search for health services is important because, based on these data, nursing professionals can interfere and educate patients, their relatives and the community. Thus, the goal of this study is to measure the time patients take to arrive at cardiac emergency service providers (delta $\mathrm{T}$ ) from the beginning of the AMI symptoms, and what influences this procedure.

\section{METHODS}

This cross-sectional study was carried out at a specialized hospital in the state of Rio Grande do Sul, Brazil, from March/2006 to August/2006. It involved conscious, oriented AMI patients with strongly uneven ST evidenced by electrocardiogram (ECG), who were older than 18 and sought emergency service (ES). The clinical conditions and enzymatic changes were registered in the patients' health records. AMI Patients with strong ST who also had hemodynamic instability, coming from admission units, presenting cardiogenic shock and patients from cities in the interior of the state were excluded.

The patients answered a questionnaire about clinical, socio-demographic and first symptoms data, considering location, characteristics, irradiation, pain intensity, associated symptoms, first reaction towards the pain and reasons for seeking specialized emergency service. The intensity of the pain was measured using a numeric scale varying from 0-10; 0 represents no pain at all and 10 represents the worst pain. The researcher applied the questionnaire during the first 24 hours of hospital admission. The outcome was delta $T$, that is, the amount of time between the beginning of the symptoms and the arrival at the Emergency Service. Comorbidities and the time of arrival at the ES were registered on the first visit report. The Research Ethics Committee of the Institution approved this project, and its goals were explained and clarified in the patients' term of consent. Statistical analysis was performed using SPSS statistical software. Continuous variables were presented as averages and standard deviation or median and interquartile percentiles according to purposes of normality; categorical variables were presented in absolute and relative frequencies. Fisher's exact test and Pearson's chi-square test were used to compare categorical variables; Student's t, Mann-Whitney and Kruskal-Wallis were used to compare continuous variables. A boxplot graph was created between delta $T$ and the patients' perception of a cardiac event. All analyses used $\alpha=5 \%$ significance level $(P<0.05)$.

\section{RESULTS}

There were 112 patients participating in the study; $80(71.4 \%)$ were men and their average age was $58 \pm 12$ years. Sixty-two (55.4\%) patients were workers; $90(80.4 \%)$ came from the city of Porto Alegre and $71(63.4 \%)$ were married (Table 1). Delta $\mathrm{T}$, the amount of time patients take to get to cardiologic emergency service since the beginning of the 
symptoms, was $3 \mathrm{hr} 59 \mathrm{~min} \pm 2 \mathrm{hr} 55 \mathrm{~min}$, on the average; 98 (88.39\%) patients sought medical services one hour after the beginning of the symptoms. The variables age $\left(r_{s}=0.12\right)$, income $\left(r_{s}\right.$ $=0.17)$ and education $\left(r_{s}=0.24\right)$ had a weak to moderate correlation with delta $T$, respectively. Table 2 shows that married, divorced and widowed patients presented higher delta $T$ than single patients. Patients with AMI or previous myocardial revascularization did not present different delta $\mathrm{T}$ when compared to the other patients.

Table 1 - Demographic and clinical characteristics (n $=112$ )

\begin{tabular}{lc}
\hline \multicolumn{1}{c}{ Characteristics } & $\mathbf{N} \%$ \\
\hline Age (in years) ${ }^{*}$ & $58 \pm 12.1$ \\
Male & $58 \pm 12.1$ \\
Married & $58 \pm 12.1$ \\
Minimum wage $\dagger$ & $3.0(2.0-5.0)$ \\
Years of education $\dagger$ & $8.0(5.0-11.0)$ \\
Worker & $62(55.4)$ \\
Therapy used & \\
$\quad$ Coronary angioplasty & $96(85.7)$ \\
$\quad$ Thrombolysis & $6(5.4)$ \\
Diabetes Mellitus & $21(18.8)$ \\
High blood pressure & $72(64.3)$ \\
Tobacco & $47(42.0)$ \\
Hyperlipidemia & $26(23.2)$ \\
Previous infarct & $26(23.2)$ \\
lschemic heart disease background & $31(27.7)$ \\
Previous revascularization & $11(9.8)$ \\
Cardiac failure & $5(4.5)$ \\
\hline
\end{tabular}

* datum presented in average and standard deviation

+ data presented with median and 25 and 75 percentiles

Table 2 - Demographic and clinical characteristics and delta $T(n=112)$

\begin{tabular}{lccc}
\hline \multicolumn{1}{c}{ Characteristics } & N \% & $\begin{array}{c}\text { Delta T } \\
\text { (hr:min) }\end{array}$ & P \\
\hline Civil status & & & \\
$\quad$ Married & $71(63.4)$ & $4: 13 \pm 3: 02$ & \\
Single & $9(8.0)$ & $1: 28 \pm 0: 55$ & 0.006 \\
Divorced & $23(20.5)$ & $3: 47 \pm 3: 09$ & \\
$\quad$ Widowed & $9(8.0)$ & $4: 16 \pm 1: 36$ & \\
Place of origin & & & \\
$\quad$ Porto Alegre & $90(80.4)$ & $3: 38 \pm 2: 59$ & 0.004 \\
$\quad$ Metropolitan area & $22(19.6)$ & $5: 00 \pm 2: 29$ & \\
Means of transportation* & & & \\
Car & $67(59.8)$ & $2: 56 \pm 2: 22$ & 0.000 \\
Ambulance & $43(38.4)$ & $5: 31 \pm 3: 06$ & \\
Previous AlM & & & \\
$\quad$ Yes & $23(20.5)$ & $3: 20 \pm 2: 24$ & 0.292 \\
No & $89(79.5)$ & $4: 03 \pm 3: 03$ & \\
Previous Myocardial Revascularization & & \\
Yes & $11(9.8)$ & $3: 47 \pm 3: 07$ & 0.879 \\
No & $101(90.2)$ & $3: 55 \pm 2: 56$ & \\
\hline
\end{tabular}

Delta $T$ is presented in average $\pm \mathrm{sd}$

* Two patients from the sample are not in this chart because they took the bus.
Eighty-nine patients ( $84 \%$ ) had burning retrosternal pain followed by pressing retrosternal pain. In $82(73.2 \%)$ patients, this pain irradiated to other parts of the body, such as the upper limbs [24 $(29.3 \%)]$. The patients also presented other symptoms like sudoresis [35 patients (38.8\%)], nausea and vomiting [24 patients (26.6\%)], but only $22(19.6 \%)$ patients felt only that kind of pain. Sixtythree $(56.3 \%)$ patients were doing some activity when they first felt the AIM symptoms. The patients gave different reasons for not seeking a specialized emergency service promptly; thirty-seven (33\%) patients stated that their first reaction was selfmedicating when they started feeling pain; 34 (30.4\%) patients expected that the thoracic discomfort and symptoms would disappear without the use of medication and $15(13.3 \%)$ patients asked relatives, friends and/or neighbors for help. Only 36 (32.1\%) patients decided to go to a specialized service by themselves, because they noticed that they were feeling symptoms of a heart condition; 26 patients $(23.2 \%)$ went to the emergency service when their retrosternal pain worsened, and 21 patients (18.8\%) sought the emergency service when their medication, for example sublingual nitrate, did not relieve their pain (Table 3 ).

Table 3 - Delta T according to circumstantial and subjective variables mentioned by the patients $(\mathrm{n}=$ 112)

\begin{tabular}{|c|c|c|c|}
\hline Variables & $\mathbf{N} \%$ & $\begin{array}{c}\text { Delta } \\
\mathrm{T}(\mathrm{hr}: \mathrm{min})\end{array}$ & $\mathbf{P}$ \\
\hline \multicolumn{4}{|l|}{ Intensity of the pain $(0-10)$} \\
\hline $8-10$ (intense) & $92(82.1)$ & $3: 47 \pm 2: 52$ & \multirow{2}{*}{0.361} \\
\hline -7 (mild to moderate) & $20(17.8)$ & $4: 27 \pm 3: 15$ & \\
\hline \multicolumn{4}{|l|}{ First reaction to the pain } \\
\hline Self-medication & $37(33.0)$ & $3: 36 \pm 2: 24$ & \\
\hline $\begin{array}{l}\text { Expecting that the symptoms would } \\
\text { disappear }\end{array}$ & $34(30.4)$ & $4: 29 \pm 3: 29$ & \\
\hline $\begin{array}{l}\text { Asking help from relatives/friends or } \\
\text { ambulance service }\end{array}$ & $15(13.3)$ & $3: 21 \pm 2: 01$ & \multirow[t]{3}{*}{0.193} \\
\hline $\begin{array}{l}\text { Seeking a healthcare center or non- } \\
\text { specialized service }\end{array}$ & $9(8.0)$ & $4: 35 \pm 2: 53$ & \\
\hline Others & $17(15.2)$ & $3: 35 \pm 3: 32$ & \\
\hline \multicolumn{4}{|l|}{ Reasons to turn to a specialized service } \\
\hline $\begin{array}{l}\text { Noticing that the symptoms are } \\
\text { related to a cardiac condition }\end{array}$ & $36(32.1)$ & $3: 16 \pm 2: 32$ & \multirow{5}{*}{0.083} \\
\hline Increased pain & $26(23.2)$ & $3: 54 \pm 2: 32$ & \\
\hline $\begin{array}{l}\text { Self-medication did not relieve the } \\
\text { pain }\end{array}$ & $21(18.8)$ & $4: 39 \pm 3: 20$ & \\
\hline Insistence of a relative or friend & $16(14.3)$ & $4: 51 \pm 4: 08$ & \\
\hline Transference from a general hospital & $13(11.6)$ & $3: 20 \pm 1: 56$ & \\
\hline
\end{tabular}


Patients whose pain irradiated to other parts of the body reported stronger pain $(8.6 \pm 1.8)$ than patients whose pain did not. $(7.8 \pm 2.3)(P=0.03)$. Patients who had not considered thoracic pain as a heart condition presented lower delta T (3hr16min \pm $2 \mathrm{hr} 32 \mathrm{~min})$ than patients who had (4hr13min $\pm 3 h r 04 m i n)(P=0.041)$.

\section{DISCUSSION}

It is known that the significance of coronary arterial recanalization in the development of AMI with strongly uneven ST segments depends on the patients' perception of the symptoms and how fast they seek emergency services. However, evidence shows that there are different reasons for them to delay going to emergency services ${ }^{(7-9)}$.

In this study, average delta $\mathrm{T}$ was 3hr11min, the same as in a previous study, whose goal was to compare how long it took from the beginning of the symptoms until hospital admission in four countries. Average delta $T$ in the U.S.A. was 3hr50min; in South Korea, 4hr40min; in Japan, 4hr50min and in England, $2 \mathrm{hr} 50 \mathrm{~min}^{(10)}$. In another study in Northern Ireland, average delta $\mathrm{T}$ was $2 \mathrm{hr} 15 \mathrm{~min}^{(7)}$. All delta $\mathrm{T}$ values found are different from recommendations by the American Heart Association(11). In this study, education, gender and age were not determining in the analysis of the time patients took to seek for a cardiac service. However, literature shows that women and elderly people take more time to go to an emergency service ${ }^{(6,8,12)}$. This study also showed a longer average time for patients who used ambulance services in relation to the others, and this fact contradicts other studies which state that the average time from the beginning of the pain to the moment they get to the emergency service decreases when using ambulance services ${ }^{(9-10)}$. The request for ambulance services and the patient's assistance depends on some factors, such as: availability of ambulance services and distance to the healthcare service. Besides, the ambulance can transfer the patient to the nearest health service, which may not be specialized and lack the resources to help AMI patients. Using previous medication during thoracic pain crisis, which increases delta $T$, is another determining factor for not rushing to an emergency service. A great part of the sample had an AMI background, and the patients were used to selfmedication. A study with 403 Swedish patients showed that $70 \%$ of them with angina background used nitrate to relieve pain before going to the doctor ${ }^{(9)}$. According to both studies and to our professional experience with cardiac patients, they are often told to use nitrate for thoracic discomfort. Those guidelines can influence the patient to make a decision about going to an emergency service, because even some relief can make patients relate their problem to more serious conditions.

It is also important to mention that the patients can delay a trip to a specialized service because they tend to go to healthcare clinics or healthcare units beforehand, and those kinds of services are not prepared to diagnose and treat AMI properly; thus, the patient has to be transferred to larger healthcare centers and this influences delta $\mathrm{T}^{(12)}$. It could be concluded that the amount of ambulances available for transportation, training courses for groups who deliver pre-hospital care in cases like as acute myocardial ischemia, lack of berths in emergency or intensive therapy centers belonging to the single health system in regional hospitals influence the delta $\mathrm{T}$ of patients from the metropolitan area, with higher delta $T$ results than patients living in the state capital. Recognizing the signs and symptoms of cardiac conditions was determining to seek emergency services, and, consequently, to have lower delta T. Previous studies confirm that patients who can recognize AMI symptoms go to emergency services as soon as they notice them, and thuspresent lower delta $T^{(13-14)}$. This study shows that, if delta $T$ is compared to an AMI background, it decreases. So, it can be concluded that patients who can recognize cardiac symptoms early better understand the disease because of a previous experience.

Patient and family education is the main strategy to promote health. Considering that the patient usually has family support, relatives must also be educated about health. In a modern health education perspective, the educator is the facilitator of the subjects' findings and reflections about reality, and the individuals have the power and autonomy to choose the possibilities ${ }^{(15)}$. At those moments, the professionals can identify what is missing, what was not understood and the gap between what was said or written and what is understood and how it is understood, in terms of knowledge about health and health habits; fantasies, taboos, difficulties in being a patient or a patient's relative and in being sick ${ }^{(16)}$. The nurse is one of the main mediators of the teachinglearning process, aiming at health promotion, focusing on understanding the signs and symptoms of eminent cardiovascular conditions and the value of going to specialized services immediately ${ }^{(17)}$. 


\section{CONCLUSIONS}

In spite of potential benefits of early care delivery to AMI patients, few patients are treated within the first 60 to 90 minutes after the beginning of the signs and symptoms. In this study, the average delta T was $3 \mathrm{hr} 59 \mathrm{~min} \pm 2 \mathrm{hr} 55 \mathrm{~min}$, and most of the sample sought medical help one hour after the onset of the symptoms. Marital status, patient origins, means of transportation and education influenced the delay in seeking for emergency services, and consequently increased delta $\mathrm{T}$. The data presented confirmed the need for local and national preventive measures, as well as information campaigns to educate people about the risks and clinical symptoms of AMI.

\section{REFERENCES}

1. Piegas LS, Timerman A, Nicolau JC, Mattos LA, Rossi JM Neto, Feitosa GS. III Diretriz sobre o Tratamento do Infarto Agudo do Miocárdio. Arq Bras Cardiol 2004 September; 83(suppl 4): 3-86.

2. Timerman A, Feitosa GS. Síndromes Coronárias Agudas. São Paulo: Atheneu; 2003.

3. Kereiakes DJ, Weaver WD, Anderson JL, Feldman T, Gibler $B$, Aufderheide $T$, et al. Time delays in the diagnosis and treatment of acute myocardial infarction: a tale of eight cities. Report from the Pre-Hospital Study Group and the Cincinnati Heart Project. Am Heart J 1990 October; 120(4): 773-80. 4. Lee TH, Weisberg MC, Brand DA, Prouan GV, Goldman L. Candidates for thrombolysis among emergency room patients with acute chest pain. Potencial true-and false - positive rates. Ann Intern Med 1989 June; 110(12): 957-62.

5. Luepker RV, Murray DM, Jacobs DR Jr. Community education for cardiovascular disease prevention: risk factor changes in the Minnesota Heart Health Program. Am J Public Health 1994 September; 84(9):1383-93.

6. Mansur AJ, Curati JAE, Almeida AO, Genari A Filho, Barreto $A C P$, Ramires JAF, et al. Infarto Agudo do Miocárdio. Comparação entre os fatores que influem no tempo decorrido entre o início da dor e a hospitalização em São Paulo e Jundiaí. Arq Bras Cardiol 1983 September; 41(3):181-84.

7. Carney R, Fitzsimons D, Dempster M. Why people experiencing acute myocardial infarction delay seeking medical assistance. Eur J Cardiovasc Nurs 2002 December; 1(4): 237- 42 .

8. Luepker RV. Delay in acute myocardial infarction: Why don't they come to the hospital more quick and what can we do to reduce delay? Am Heart J 2005 September; $150(3): 368-70$.

Recebido em: 6.6.2007
Preventing new situations and making people aware of the decrease of modifiable risk factors should be emphasized. Healthcare professionals who work with education should broaden their praxis to give some information in order to stimulate people's and the community's senses, that is, the perception of the individual, establishing relationships and offering solutions for common problems ${ }^{(18)}$. Health education predicts community awareness, arousing individual capacities in relation to their real health needs ${ }^{(15)}$. This study shows that some patients were transferred from other institutions, especially in the metropolitan area. They had an increased delta $\mathrm{T}$ since transference often depends on acceptance and available berths at other institutions.

9. Johansson I, Strömberg A, Swahn E. Factors related to delay times in patients with suspected acute myocardial infarction. Heart Lung 2004 September-October; 33(5):291300.

10. McKinley S, Dracup K, Moser DK, Ball C, Yamasaki K, Kim $\mathrm{C}$, et al. International comparison of factors associated with delay in presentation for AMI treatment. Eur J Cardiovasc Nurs 2004 September; 3(3):225-30.

11. Antman EM, Anbe DT, Armstrong PW, Bates ER, Green LA, Hand M, et al. ACC/AHA guidelines for the management of patients with ST-elevation myocardial infarction; A report of the American College of Cardiology/American Heart Association Task Force on Practice Guidelines (Committee to Revise the 1999 Guidelines for the Management of patients with acute myocardial infarction). J Am Coll Cardiol 2004 August $4 ; 44(3)$ :E1-E211.

12. Franken RA, Souza $A B$, Hungria VT, Golin V. Infarto do Miocárdio. A chegada do paciente ao hospital. Arq Bras Cardiol 1985 May; 44(5): 323-5.

13. Goff DC Jr., Mitchell P, Finnegan J, Pandey D, Bittner V, Feldman $\mathrm{H}$, et al. Knowledge of heart attack symptoms in 20 US communities. Results from the rapid early action for coronary treatment community trial. Prev Med 2004 January; 38: 85-93.

14. Ottesen MM, Dixen U, Torp-Pedersen C, Kober L. Prehospital delay in acute coronary syndrome - analysis of the components of delay. Int J Cardiol 2004 July; 96(1):97103.

15. Oliveira DLLC. A 'nova' saúde pública e a promoção da saúde via educação: entre a tradição e a inovação. Rev Latinoam Enfermagem 2005 Maio-Junho; 13(3): 423-31.

16. Souza LM, Wegner W, Gorini MLPC. Educação em saúde: uma estratégia de cuidados ao cuidador leigo. Rev Latino-am Enfermagem 2007 Março-Abril; 15(2): 337-43.

17. Mussi FC. $\mathrm{O}$ infarto e a ruptura com o cotidiano: possível atuação da enfermagem na prevenção. Rev Latino-am Enfermagem 2004 setembro-outubro; 12(5): 751-9.

18. Pedroso M. O significado do cuidar de si mesmo para os educadores em saúde. [dissertação]. Porto alegre (RS): Escola de Enfermagem/UFRGS: 2000. 